\title{
Research on the Impact of China's Manufacturing Social Responsibility on Financial Performance
}

\author{
Wen $\mathrm{Li}^{1}{ }^{1,}$, Xiaoxiao $\mathrm{Ma}^{2, b}$ \\ ${ }^{1}$ No. 705, Rong Jiang Road, Daoli District, Harbin, Heilongjiang, China \\ ${ }^{2}$ Zhaoyuan County, Daqing, Heilongjiang, China \\ ahrbsydxlw@163.com, bmxxhsd111@163.com
}

Keywords: manufacturing; social responsibility; financial performance.

\begin{abstract}
This paper takes the manufacturing companies from the list of 2016 China's A-shares public companies as empirical samples, based on required indicators of the social responsibility measurement method that mentioned in the "Notice of the Shanghai Stock Exchange on Strengthening the Social Responsibility of Listed Companies" issued by the Shanghai Stock Exchange in 2008. These conclusions can help us understand the relationship between companies social responsibilities and financial performances deeply, guide enterprises to treat social responsibility correctly and completely, and the short-term performance of taking social responsibilities could be benefit to improve financial performances.
\end{abstract}

\section{Introduction}

With the rapid development of economy, on the one hand, some enterprises have begun to pay attention to the fulfillment of social responsibilities in the process of their own growth. As of December 31, 2015, 701 A-share listed companies issued social responsibility reports, of which Baosteel Group saved 346,200 tons of coal annually, and the conversion rate of solid waste reached $60.2 \%$, which indirectly created over 100 million yuan value.

In recent years, Chinese scholars have also studied the relationship between social responsibility performance and corporate financial performance, but most of them have divided social responsibilities into multiple dimensions, and have not linked it to the financial performance.

\section{Literature Review}

Chinese scholars have studied social responsibility and financial performance of different industries. Li Wei (2012) conducted research based on the transportation industry. He selected the data of transportation industry companies from the list of public companies in 2009, and studied the relationships among social responsibility, financial performance and the continuous growth of the company. When considering continuous growth, the social responsibility of the transportation industry has a positive correlation with financial performance, but the relationship is not obvious. Wei Liling (2016) conducted a research on the food industry and analyzed the impact of food companies on the financial performance when they take the responsibilities of creditors, suppliers and so on. The conclusion presents a significant positive correlation. When it comes to social responsibility, scholars in different countries also have different measurement methods. Some scholars based on financial report data to calculate social responsibility.

\section{Theoretical Analysis and Hypothesis Formulation}

Modern enterprises often use product innovation and process innovation to increase their core competitiveness in order to obtain excess profits. There are various ways to fulfill social responsibility and promote the improvement of corporate performance. The Ministry of Environmental Protection issued a document on "Implementation of Environmental Protection 
Policies and Regulations to Prevent Credit Risks”, pointing out that enterprises with serious pollution and poor standards of pollutant discharge should raise their equity refinancing requirements.

\section{Research Design}

\subsection{Samples and data}

This paper selects the financial information of the manufacturing A-share companies from 2016 annual report which have released on March 1, 2017, and finally obtained 317 companies' data. All the data come from Guotaian database, Shanghai Stock Exchange and Shenzhen Stock Exchange official website.

\subsection{Variable Definition}

Social responsibility indicators. The formula is social contribution value $=$ net profit + various taxes paid - tax refunds received + payment Cash paid to employees and employees + cash paid for interest + dividends paid + charitable donations + sponsorship fees - other social costs due to environmental pollution.

Financial performance indicators. In financial analysis, multiple types of indicators are often used, such as profitability indicators, asset utilization indicators and solvency indicators, etc. Therefore, comprehensive indicators are needed to cover other indicators.

Control variable selection. In order to make our research more practical, we selected two control variables, firm size and firm nature, which combined with the selection of control variables in the relevant literature (Wen Subin 2008, Fernando, 2008).

Table 1

\begin{tabular}{lccc}
\hline \multicolumn{2}{c}{ Variable type } & Variable & Variable name \\
\hline \multirow{2}{*}{ Dependent variable } & Financial & Total return on assets & ROA \\
& performance & Return on equity & ROE \\
Independent variable & Social responsibility & Social contribution & SHGXZ \\
\multirow{2}{*}{ Control variable } & Enterprise size & SIZE \\
& & Corporate nature & OWENER \\
\hline
\end{tabular}

\subsection{Construction of the model}

Combining the above-listed dependent variables, independent variables and control variables, with the total return on assets, social contribution value, firm size and enterprise nature as variables, construct a multiple linear regression model. The specific model is as follows:

$$
\mathrm{ROA}=\alpha 1 \mathrm{SHGXZ}+\alpha 2 \mathrm{SIZE}+\alpha 3 \mathrm{OWENER}+\varepsilon
$$

\section{Empirical Analysis}

\subsection{Correlation analysis}

This paper uses Pearson correlation to check the correlation of variables. First, we can see that there is a significant positive correlation between the ROA and the variable SHGXZ. In line with our previous assumptions. Secondly, we can also find that the relationship between the variable SHGXZ and the variables SIZE and OWENER is a significant positive correlation. 
Table 2 Correlation

\begin{tabular}{lllllll}
\hline & & ROA & ROE & SHGXZ & OWENER & SIZE \\
\hline ROA & (Pearson)Relevance & 1 & $.690^{* *}$ & $.343^{* *}$ & $-.167^{* *}$ & 0.045 \\
& Significance & & 0 & 0 & 0.003 & 0.429 \\
& $\mathrm{~N}$ & 317 & 317 & 317 & 317 & 317 \\
ROE & (Pearson)Relevance & $.690^{* *}$ & 1 & $.338^{* *}$ & -0.047 & $.209^{* *}$ \\
& Significance & 0 & & 0 & 0.405 & 0 \\
& $\mathrm{~N}$ & 317 & 317 & 317 & 317 & 317 \\
SHGXZ & (Pearson)Relevance & $.343^{* *}$ & $.338^{* *}$ & 1 & $.325^{* *}$ & $.821^{* *}$ \\
& Significance & 0 & 0 & & 0 & 0 \\
& $\mathrm{~N}$ & 317 & 317 & 317 & 317 & 317 \\
\multirow{5}{*}{ OWENER } & (Pearson)Relevance & $-.167^{* *}$ & -0.047 & $.325^{* *}$ & 1 & $.356^{* *}$ \\
& Significance & 0.003 & 0.405 & 0 & & 0 \\
& $\mathrm{~N}$ & 317 & 317 & 317 & 317 & 317 \\
\multirow{5}{*}{ SIZE } & (Pearson)Relevance & 0.045 & $.209^{* *}$ & $.821^{* *}$ & $.356^{* *}$ & 1 \\
& Significance & 0.429 & 0 & 0 & 0 & 317 \\
$* *$ & $\mathrm{~N}$ & 317 & 317 & 317 & \\
& Correlation is significant at the 0.01 level (two-tailed) & & & \\
& & & & & \\
\hline
\end{tabular}

\subsection{Regression analysis}

At the same time, we can see that the adjusted R-square is 0.337 , and the variability of each variable is 0 , indicating that the model has better explanatory ability and the coefficient of social contribution is positive.

Table 3 Regression summary

\begin{tabular}{cccc}
\hline Model number & $\mathrm{R}$ & R squared & Justed R squared \\
\hline 1 & 586 & 0.343 & 0.337 \\
& A Predicted value: (constant),SIZE, OWENER, SHGXZ \\
\hline
\end{tabular}

\subsection{Analysis of variance}

Table 4 Regression coefficients

\begin{tabular}{ccccc}
\hline Model & $\begin{array}{c}\text { Non-standardized } \\
\text { coefficient }\end{array}$ & $\begin{array}{c}\text { Normalization } \\
\text { coefficient }\end{array}$ & $\mathrm{T}$ & Significant \\
\hline
\end{tabular}

B Standard error Beta

$\begin{array}{ccccccc} & \text { (constant) } & -0.074 & 0.05 & & -1.474 & 0.141 \\ & \text { SHGXZ } & 0.095 & 0.008 & 0.967 & 12.024 & 0 \\ & \text { OWENER } & -0.028 & 0.006 & -0.246 & -5.002 & 0 \\ & & & & & \\ & \text { SIZE } & -0.072 & 0.009 & -0.662 & -8.138 & 0\end{array}$

Dependent variable: ROA

First of all, the social responsibility of the enterprise will be grouped first, taking 8.66 of the SHGXZ value as the dividing line, and the enterprises above 8.66 are defined as more enterprises fulfilling social responsibility. The statistical results are shown in the table 
Table 5 Statistical data

\begin{tabular}{ccccc}
\hline Group & $\mathrm{N}$ & Average number & Standard deviation & Standard deviation error average \\
\hline 2 & 129 & 0.06691726 & 0.054596801 & 0.004825721 \\
1 & 188 & 0.04881561 & 0.04955536 & 0.003614196 \\
\hline
\end{tabular}

The statistical results are shown below the table. It can be seen that there is a homogeneity of variance between the groups. From the results of the T test, it can be seen that the ROA of different groups has significant differences.

Table 6 One-way variance homogeneity test

\begin{tabular}{|c|c|c|c|c|c|c|}
\hline \multicolumn{3}{|c|}{ ROA } & \multicolumn{2}{|r|}{$\mathrm{F}$} & \multicolumn{2}{|c|}{ significant } \\
\hline & & & \multicolumn{2}{|c|}{1.6920} & \multicolumn{2}{|c|}{0.194} \\
\hline \multicolumn{7}{|c|}{ Table $7 \mathrm{~T}$ test } \\
\hline \multirow[t]{2}{*}{$\mathrm{T}$} & $\mathrm{df}$ & Significant & $\begin{array}{l}\text { Average } \\
\text { difference }\end{array}$ & $\begin{array}{l}\text { Standard } \\
\text { error }\end{array}$ & $\begin{array}{c}\text { Confidence interval o } \\
\text { difference }\end{array}$ & \\
\hline & & & & & Lower limit & Top limit \\
\hline 3.058 & 314 & 0.002 & 0.018 & 0.00591 & 0.006455388 & 0.029747904 \\
\hline 3.002 & 54.953 & 0.003 & 0.018 & 0.00602 & 0.006228473 & 0.029974819 \\
\hline
\end{tabular}

\section{Research conclusions and recommendations}

This paper conducts an empirical analysis of the relationship between social responsibility and financial performance of manufacturing listed A-share companies. The following conclusions are drawn: (1) The fulfillment of social responsibility can improve the financial performance of the company. (2) It can be seen that fulfilling social responsibilities in the current period is also helpful for improving financial performance.

Make relevant recommendations based on the above conclusion:

Manufacturing need to understand the short-term and long-term benefits of fulfilling social responsibilities. At the same time, if companies want to exert the positive impact of social responsibility, it is important to understand the each stakeholder in details.

Strengthen the awareness of corporate social responsibility through government supervision and the public supervision. We need more detailed disclosure of social responsibility or increase fulfillment of corporate social responsibility, and companies require to raise their awareness of social responsibility. First of all, as a stakeholder, the government, the society, upstream and downstream suppliers need to improve their understanding and attention to social responsibility.

Introduce key social responsibility related data into traditional financial statements. In the process of conducting empirical research, we found the calculation of the social contribution value in the "Notice of the Shanghai Stock Exchange on Strengthening the Social Responsibility of Listed Companies", such as public welfare donation expenditure, sponsorship fees, and other social costs caused by environmental pollution. It is important to list relevant important data in the existing balance sheet, and the relevant information can also be disclosed in the notes to the statement.

\section{Acknowledgements}

This paper is the phased achievement of the 2017 Heilongjiang Provincial Philosophy and Social Science Project "Influence of BT reforms to VAT on the Financial Performance of Heilongjiang 
Listed Companies” (Approval No.17GLD172)

\section{References}

[1] Amran A. The influence of governance structure and strategic corporate social responsibility toward sustainability reporting quality [J]. Business Strategy and the environment, May. 2013(11): 1.

[2] Li Wei. Research on the Relationship between Corporate Social Responsibility and Financial Performance_-Based on Data Analysis of Listed Companies in the Transportation Industry [J]. Studies in Financial and Economic Issues, 2012(49):99.

[3] Shao Cuili. Research on the Impact of Corporate Social Responsibility on Financial Performance_-Taking Listed Companies in Paper Industry as an Example [J]. Friends of Accounting, 2016(24): 25.

[4] Wei Liling. Research on the Relationship between Corporate Social Responsibility and Financial Performance_- Taking Food and Beverage Manufacturing as an Example [J]. Journal of Southeast University, 2016(12): 23.

[5] Wen Subin.An Empirical Study on the Relationship between Corporate Social Responsibility and Financial Performance: Panel Data Analysis from the Perspective of Stakeholders [J].Chinese industrial economy, 2008(10): 17. 